\title{
THE ROLE OF INTERFERON-GAMMA RELEASE ASSAY IN TUBERCULOSIS CONTROL
}

\author{
Anamarija JURČEV-SAVIČEVIĆ ${ }^{1}$, Vera KATALINIĆ-JANKOVIĆ ${ }^{2}$, Kornelija MIŠE³, \\ and Ivan GUDELJ ${ }^{3}$ \\ Teaching Public Health Institute of Split and Dalmatia County and School of Medicine University of Split, Split ${ }^{1}$, \\ Croatian National Institute of Public Health Zagreb ${ }^{2}$, Split University Hospital, Department of pulmonary diseases, \\ and School of Medicine University of Split, Split ${ }^{3}$, Croatia \\ Received in July 2011 \\ CrossChecked in October 2011 \\ Accepted in January 2012
}

\begin{abstract}
Tuberculosis is still one of the major global public health threats. Countries with low incidence must focus on exhausting the reservoir of future cases by preventing reactivation. Therefore, it is important to identify and effectively treat those individuals who have latent tuberculosis infection and who may develop active disease. The tuberculin skin test has been the standard for detection of immune response against $M$. tuberculosis since the beginning of the $20^{\text {th }}$ century. The new millennium has brought advancement in the diagnosis of latent tuberculosis infection. The name of the new blood test is interferon-gamma release assay (IGRA). Croatia is a middle-incidence country with a long decreasing trend and developed tuberculosis control. To reach low incidence and finally eliminate tuberculosis, its tuberculosis programme needs a more aggressive approach that would include intensive contact investigation and treatment of persons with latent tuberculosis infection. This article discusses the current uses of IGRA and its role in tuberculosis control.
\end{abstract}

KEY WORDS: Croatia, enzyme-linked immunospot assay, latent tuberculosis infection, QuantiFERONTB Gold In-Tube, tuberculin skin test

Tuberculosis (TB) control is the most effective if TB is detected and treated early. National tuberculosis programmes (NTP) in high-incidence countries without sufficient resources are therefore focused on early detection and treatment. In turn, tuberculosis elimination strategies in low-incidence countries focus on exhausting the reservoir of future cases by preventing reactivation. They seek to identify and effectively treat individuals who have latent tuberculosis infection (LTBI) and who may develop active disease in their lifetime (1).

Croatia is a middle-incidence country with a long decreasing trend and advanced tuberculosis control (2). To reach low incidence and finally eliminate tuberculosis, its NTP needs a more aggressive approach that would include intensive contact investigation to identify, treat, and follow up individuals with LTBI according to the national guidelines (3).

There is no possibility to be sure that a person thought to have latent tuberculosis infection actually carries viable $M$. tuberculosis (4). What can be identified is a cell-mediated memory against mycobacterial antigens. For over 100 years this immune response against $M$. tuberculosis has been screened for using the tuberculin skin test (TST). It involves intradermal injection of purified protein derivative (PPD), which is a mixture of more than 200 
antigens that lead to a delayed hypersensitivity reaction, visible as a local skin induration. The antigen spectrum of PPD is shared by the M. tuberculosis complex, Bacillus Calmette-Guerin (BCG)-subtype of $M$. bovis, and nontuberculous mycobacteria. As BCG vaccination has been a part of the Croatian national immunisation programme since 1948, TST has shown limited performance in diagnosing LTBI, as it gets confounded by prior BCG vaccination. With a new test called interferon-gamma release assay (IGRA), the new millennium has brought advance in identifying immunological response against antigens of Mycobacterium tuberculosis to clinical practice and tuberculosis control (5). A number of studies, many of them referred to in this article, have found IGRA a promising assay, but have also raised many questions to be answered. This is not surprising, as the nature of tuberculosis and immune response are still not fully understood.

Tests based on immunological memory, be they TST or IGRA, share an important limitation; they do not directly detect the presence of M. tuberculosis, but identify immune response to recent or remote infection with M. tuberculosis (4). However, IGRA overcomes the main limitation of TST, which is the lack of species specificity. It measures interferon-gamma (IFNgamma), a cytokine released by sensitised T-cells in response to mycobacterial antigens present in the $M$. tuberculosis complex and absent from the BCG-strain and from the most nontuberculous mycobacteria except M. kansasii, M. marinum and M. szulgai.

Two types of IGRAs are currently available: the ELISpot test (enzyme linked immunospot assay), that directly counts the number of IFN-gamma secreting T-cells (commercially available as the T-SPOT.TB, Oxford Immunotec Ltd, Abingdon, UK) and the ELISA test (enzyme linked immunosorbent assay), that measures the concentration of secreted IFNgamma. Several generations of the ELISA test have been developed by Cellestis Ltd, Carnegie, Australia.

The first was with PPD as the antigen, which is not longer commercially available; the second was QuantiFERON ${ }^{\circledR}$-TB Gold (QFT-G), with early secretory antigenic target-6 (ESAT-6) and culture filtrate protein-10 (CFP-10); and finally QuantiFERON ${ }^{\circledR}$-TB Gold In-Tube (QFT-G-IT), with ESAT-6, CFP-10, and TB7.7.

This latest generation has currently been used in Croatia by a limited number of hospitals and public health institutes. It is more sensitive than the earlier one, probably because of the additional TB7.7 antigen ( $83 \%$ vs. $93 \%, \mathrm{p}=0.006$, respectively) (6).

\section{QFT-G-IT TESTING}

The testing procedure is as follows; three millilitres of collected blood is distributed in three tubes $(1 \mathrm{~mL}$ each): the nil tube (heparin-only negative control tube), the TB antigen tube, and the mitogen tube (phytohaemagglutinin positive-control tube). Immediately after filling, the tubes have to be shaken ten (10) times to coat the entire tube wall with blood that will solve the antigens on the wall.

Within $16 \mathrm{~h}$ of blood collection, the tubes need to be incubated for $16 \mathrm{~h}$ to $24 \mathrm{~h}$ and ELISA test performed. The results are software-reported automatically as positive if the reaction to TB antigens is $\geq 0.35 \mathrm{IU} \mathrm{mL}^{-1}$ after subtracting the nil control (7). This points to a likely M. tuberculosis infection. For now, the cut-off of $\geq 0.35 \mathrm{IU} \mathrm{mL}^{-1}$ IFN-gamma has been taken as an optimal combination of sensitivity and specificity. The positive result does not distinguish between recent and remote infection or between active TB and LTBI. In this respect, it is no better than TST. The reason why that QFT-G-IT does not say much about the activation of the immune response in tuberculosis is that it uses peripheral blood that contains much less memory T-cells than the site of infection in active disease (8). Therefore, interpretation should not rely on the positive result alone, but should include risk factors to compensate for suboptimal sensitivity and the possibility of cross-reaction with three nontuberculous mycobacteria.

A negative result suggests that $M$. tuberculosis infection is not likely. However, if TB is suspected, negative result alone can not rule out active disease (8). IGRA conversion usually takes four to seven weeks following exposure to TB, but conversions can also take 14 to 22 weeks (9).

With an indeterminate result, LTBI can neither be excluded nor confirmed. If blood cells have not responded to a positive control there may have been an error in performing the test or the subject's immune system may be suppressed. By including an internal positive control (mitogen tube), it is possible to distinguish between indeterminate results and those that are truly QFT-negative. In contrast, a negative TST does not differentiate between immune suppression or false test performance and truly negative result (7). Indeterminate results are usually associated with 
young ( $<5$ years) and old ( $>80$ years) age and immunosuppression, such as that owed to HIV infection or immunosuppressant therapy $(10,11)$. New guidelines recommend to retest the person with indeterminate result. If the result remains indeterminate, this may point to T-cell anergy (12).

\section{THE MOST IMPORTANT IGRA FEATURES}

Many studies have reported on IGRA's performance. They differ in regard to TB incidence, prevalence of infection, patient age, status of the immune system, prevalence of HIV-coinfection, antigens used (older or newer generation), and tuberculin units used during TST. This article has focused on newer studies published in prestigious scientific journals, performed in settings similar to ours.

\section{Sensitivity}

The sensitivity and specificity of IGRAs or TST for LTBI cannot be reliably estimated because there is no gold method for the diagnosis of LTBI. This is why two surrogates for infection are used to estimate sensitivity. One is active TB. In a recent meta-analysis (13), pooled sensitivity of QFT-G-IT, T-SPOT.TB, and TST was $80 \%, 81 \%$, and $65 \%$, respectively. Similar meta-analysis are consistent; the sensitivity of both IGRAs are usually higher than that of TST $(6,11$, 14-16).

Even though not all individuals exposed to TB will become infected, the second approach to estimate sensitivity is based on the assumption that some of them will, depending on the frequency, length, and proximity of contact with infectious TB patient (17). Exposure to a TB patient is often used as the infection surrogate to estimate test performance in an epidemic or contact investigation. Even though more studies have estimated T-SPOT.TB sensitivity than that of QFT, they all show that both tests better correlate with TB exposure than TST and do not depend of BCG vaccination $(11,16,18,19)$. To conclude, even though either IGRA is more sensitive than TST, their sensitivities are suboptimal and we still need to find a more sensitive method.

\section{Specificity}

In areas with low TB incidence the prevalence of LTBI is expected to be very low among unexposed individuals. Therefore, where LTBI has not been established, test specificity is assessed in healthy subjects without known exposure. A recent metaanalysis (20) reported that QFT specificity ranged between $92 \%$ to $100 \%$ and pooled specificity was $98 \%$. Pai et al. (14) reported that pooled specificity of QFT tests was higher among non BCG-vaccinated individuals (99\%) than among vaccinated (96\%), while pooled specificity of T-SPOT.TB was $93 \%$. TST specificity was high in populations that had not received BCG (97\%), but usually low among BCGvaccinated individuals (59\%) (16). Overall, IGRAs have a higher specificity than TST, particularly in BCG-vaccinated population.

\section{PREDICTIVE VALUE OF IGRA IN THE DEVELOPMENT OF ACTIVE DISEASE}

Preventive treatment of IGRA-positive contacts in comparison with IGRA-negative contacts will be reasonable only if their risk of progression to tuberculosis is higher. At the moment, no correlation has been established between IFN-gamma responses and the stage or degree of infection, the level of immune responsiveness, or the probability of progression to active disease. However, some findings suggest that QFT may be able to predict progression to active disease better than TST (21). In recent contacts with infectious cases, IGRA-positive tests better correlate with M. tuberculosis exposure than TST-positive findings. During a follow-up of an average of 3.7 years after exposure to TB, $12.9 \%$ of QFT-positive contacts who refused chemoprevention developed TB in comparison with $3.1 \%$ of TST positives ( $>5 \mathrm{~mm}$ of induration) (21). Several studies suggest that IGRAs are superior to TST in predicting active TB in BCG-vaccinated recent contacts $(8,11)$. However, if active TB is suspected, other diagnostic parameters are necessary to confirm TB (eg. bacteriological confirmation).

Higuchi et al. (22) showed that after 3.5 years of follow-up, none of BCG-vaccinated contacts who were both QFT-negative and TST-positive had developed active disease. The negative predictive value for M. tuberculosis infection is $>95 \%$ for both TST and IGRA negative results $(23,24)$. This suggests that LTBI and active TB can be excluded with a high degree of certainty in immunocompetent individuals, if both tests are performed and both have negative results (25). In immunocompromised individuals, however, this prediction is very limited $(8,23,24)$. 


\section{AGREEMENT BETWEEN IGRA AND TST}

Current research has shown that the level of agreement between the IGRAs and TST is lower if the tested population received BCG. This is not surprising because TST is confounded by prior BCG vaccination. Agreement between T-SPOT.TB and TST is moderate to high, with kappa values ranging from 0.51 to 0.72 , and between QFT test and TST is more variable, with kappa values ranging from 0.19 to 0.87 (11).

However, most studies have focused on the agreement in positive vs. negative findings and have failed to view results as continuous variables. TST induration can be viewed not only as a positive or negative outcome, but also as a range of diameters. The same goes for INF-gamma results; instead dividing them into positive and negative along the cut-off value of $0.35 \mathrm{IU} \mathrm{mL}^{-1}$, they can be compared directly. Pai et al. (26) have shown that changes in cut-offs of both tests can change the level of their agreement.

\section{REPRODUCIBILITY OF IGRA}

Reproducibility of IGRAs is particularly interesting in terms of within-person variability of T-cell responses in serial testings performed in some countries $(27,28)$. IGRAs are highly dynamic tests, and T-cell responses, especially weakly positive, tend to vary. Conversions, reversions, and non-specific variations have been reported for both IGRA and TST serial testing $(18,29-31)$. The clinical significance and prognosis of IGRA conversion and reversion are not clear, and it is difficult to determine an optimal cut-off to distinguish true infection from biological variability $(27,28,30)$.

Reproducibility may be evaluated through dichotomous (positive vs. negative) results or through continuous IFN-gamma values. Reproducibility is usually analysed in two ways: a same sample is tested by two separate QFT-G-IT assays (so called test-retest variability) and the same person is tested repeatedly over a short period of time (short-term, within-person variability). When QFT-G-IT results are interpreted using dichotomous results, then test-retest and withinperson reproducibility are very high, as most of the results are well below or well above the cut-off of 0.35 $\mathrm{IU} \mathrm{mL}^{-1} \mathrm{IFN}$-gamma. Discordance is mostly present in subjects who had IFN-gamma values around the cut-off point $(28,29)$.

Using continuous IFN-gamma values to interpret QFT-G-IT results, reproducibility was moderate to high (28) or high (32). A similar study also showed that weakly positive IGRA results were subject to variation over time more than negative results which generally remained negative. Variation in strongly positive IFN-gamma values will probably not have any clinical significance, but weakly positive IFNgamma values may complicate interpretation of repeated results (30).

With dichotomous test results, conversion (which may lead to LTBI treatment) is simply defined as a change from negative to positive. Findings from reproducibility studies suggest that QFT conversion has to meet two conditions: there should be a change from a negative to a positive result and the baseline IFN-gamma value should increase at least $30 \%$ (28). The US Centers for Disease Control and Prevention recommend that both the standard qualitative test interpretation and the quantitative assay measurement should be reported together with the criteria used for test interpretation (27).

\section{IGRA IN CHILDREN}

In terms of LTBI and active TB, children run a high risk of developing active TB after being infected, and TB diagnosis is often difficult due to the paucibacillary nature of disease. Weak cellular immune response is usually the reason why IGRA results are more often indeterminate in children than in adults (33). Some even prefer TST in diagnosing LTBI in smaller children over IGRA $(27,34,35)$. This preference stems from the fact that TST obtains a stronger immunological response, as it stimulates central memory cells over a longer incubation time, while QFT responses result from effector cells in peripheral blood. In addition, the Th1 system, that produces interferon-gamma, is immature in children while the immune response of the Th2 system (interleukin 4, IFN-gamma, tumour necrosis factor alpha, interleukin 10, interleukin 12, and granulocyte colony-stimulating factor) is active and is more likely detected by TST $(19,36)$. On the other hand, several studies suggest that at higher levels of exposure to TB, the proportion of children with positive results in both IGRAs is higher, independent of the BCG status (11, 19,36). 
In a recent meta-analysis (37), pooled sensitivity of TST, QFT, and T-SPOT TB in children was $80 \%$, $83 \%$, and $84 \%$, while pooled specificity was $85 \%$, $91 \%$, and $94 \%$, respectively. All tests had lower sensitivity in young or HIV-infected children.

An Australian study (19) reported a high level of agreement between IGRAs (93\%), but often low agreement between IGRAs and TST (75\%). The size of TST induration and IFN-gamma levels were significantly associated with TB contact history, while age influenced only the TST results.

One study (38) directly compared T-SPOT.TB, QFT-G-IT, and TST performance in immunocompromised children in a setting with low TB incidence. T-SPOT.TB and QFT-G-IT yielded a high percentage of indeterminate findings (13.5\% and $20 \%$, respectively) and agreed in $62 \%$ of the cases. Excluding the indeterminate results, the IGRAs agreement with TST was low and their performance was not associated with age, sex, white blood cell count, or treatment duration.

Indeterminate results reported for immunocompetent children in Italy, tested mostly during contact investigation, were more frequent with ELISA-based, QFT-G and QFT-G-IT tests than with T-SPOT.TB. (12.6\% vs. $2.3 \%$ and $16.4 \%$ vs. $1.5 \%$, respectively). The extent of exposure to M. tuberculosis (household $v s$. casual contacts or recent immigrants) was not associated with the rate of indeterminate results for any test (33).

In general, studies evaluating IGRA performance in children are few, and many questions remain unanswered. This is probably the reason why many national guidelines recommend caution in the use of IGRA in children (UK, Netherlands, Switzerland, Canada, France, and Japan) (20).

To conclude, sensitivity may be higher in children with a high risk of infection especially in children below five years of age and in immunocompromised children when IGRA testing is done in addition to the TST $(4,39)$. Whichever test turns positive, it points to true infection. Low-risk children may benefit from IGRA as a confirmation of positive TST in terms of increased specificity and reduced risk of a false diagnosis of LTBI (4).

\section{IGRA IN IMMUNOCOMPROMISED INDIVIDUALS}

The risk of progression to active disease is higher in infected immunosuppressed patients that in general population. Therefore, this is the target group for the screening and treatment of LTBI. Different diseases and conditions have been found to have impaired cell-mediated immunity such as HIV-infection, transplantation-related immunosuppressive therapy, anti TNF-alpha or corticosteroid treatment, malignancy, and chronic renal failure/haemodialysis. Only a limited number of studies focused on the accuracy of IGRAs in LTBI diagnosis in these groups of patients.

HIV-infection is the most important risk factor for TB in infected patients. In HIV-positive patients, the sensitivity of QFT is generally lower and the percentage of indeterminate results higher than in HIV-negative individuals. Test sensitivity rises as CD4 cell count drops. A recent meta-analysis (20) showed that IGRA's pooled sensitivity in HIV-infected TB patients was much higher than that of TST (70 \% vs. $45 \%$, respectively). Another study (40) showed that T-SPOT.TB test was positive in $44.2 \%$ immunosuppressed, HIV-negative, non-BCG vaccinated persons, who had been nosocomial contacts of smear-positive TB patient, while TST was positive in $17.4 \%$ (agreement $67.8 \%$ ) In addition, T-SPOT. $T B$ test produced only $4.3 \%$ indeterminate results, regardless of the level of immunosuppression.

In a BCG-vaccinated population studied by Kim et al. (41), immunosuppression was significantly associated with the lower percentage of positive TST results $(10.3 \%$ in immunocompromised vs. 27.7 in immunocompetent patients), but not with positive QFT-G-IT results (21.4\% vs. $25.5 \%$, respectively). However, its association was significant with indeterminate QFT-G-IT results (21.4\% in immunocompromised vs. $9.6 \%$ in immunocompetent patients). Indeterminate QFT-G-IT results were associated with laboratory findings such as anaemia, lymphocytopenia, hypoproteinemia, and hypoalbuminemia. The agreement between QFT-G-IT and TST was lower in the immunocompromised than in the immunocompetent patients.

Generally, only a few studies have addressed the performance of IGRAs in these patients. Expert opinion is that immunocompromised patients could benefit from the simultaneous use of IGRAs and TST. This approach is based on the need to increase test sensitivity. Indeterminate findings do not exclude TB infection. In fact, an indeterminate result in the absence of mitogen response may suggest anergy rather than absence of infection (12). 


\section{IGRA RESPONSES DURING THERAPY}

In a study by Dyrhol-Riise et al. (42), $85 \%$ of patients receiving preventive treatment with isoniazid and rifampicin for three months were still positive to QFT-G-IT three and 15 months after treatment. Moreover, IFN-gamma levels were comparable at baseline and the three and 15 months after preventive treatment. The authors concluded that the test was not useful for monitoring preventive therapy. Similarly, Pai et al. (43) showed that $73 \%$ of patients were positive to QFT-G-IT at baseline, $81 \%$ after two months of treatment, and $79 \%$ at the end of a standard six-month treatment.

Changes in IFN-gamma were also inconclusive. Both studies suggest that IGRAs are not reliable markers to monitor the effect of therapy.

\section{IGRA IN CONTACT INVESTIGATION}

The study of QFT-G-IT performance by DyrholRiise et al. (43) conducted in a low-incidence country showed that almost $70 \%$ of the participants with positive TST results were QFT-G-IT-negative. The highest percentage of QFT-G-IT-positive results was found among household contacts (59.5\%) and among those who had TST induration $\geq 15 \mathrm{~mm}(47.5 \%)$, which is usually taken as a true positive finding. Positive QFT-G-IT results were associated with immigrants born in non-western countries with high or intermediate prevalence, then with the time of TB exposure, and with previous TB disease.

A large German comparative study (44) of TST, QFG-G-IT, and T-SPOT.TB performance in persons exposed to pulmonary tuberculosis showed that cumulative exposure time, positive smear and/or coughing of the source, age, and foreign origin of the contact were good predictors of positive QFG-G-IT and T-SPOT.TB findings. The two IGRAs agreed in $93.9 \%$ of cases $(\kappa=0.85)$. Assuming that positivity to both IGRAs was true infection, the sensitivity of TST was $72 \%$ and $39.7 \%$ at respective cut-offs of $>10$ $\mathrm{mm}$ and $>15 \mathrm{~mm}$. The authors concluded that either QFG-G-IT or T-SPOT.TB would reduce the number of LTBI suspects by approximately $70 \%$ in comparison with TST. In addition, the authors suggested that testing should be limited to contacts of smear-positive sources with $>8$ hours of cumulative exposure and contacts of smear-negative sources with $>40$ hours of cumulative exposure. However, the testing should also include contacts closely exposed to smear-positive sources, regardless of the cumulative time of exposure, as this may also lead to LTBI. The authors also pointed out that active TB could develop in IGRA-positive but TST-negative untreated patients. In other words, regardless of the cut-off point, TST may fail to detect infected contact. By raising the cut-off from $5 \mathrm{~mm}$ to $10 \mathrm{~mm}$ in BCG-vaccinated contacts, $25 \%$ of the tests turned false negative and the authors concluded that IGRAs were more accurate indicators of LTBI than TST. In line with that observation, new German guidelines (35) recommend that only IGRA is used to test adult contacts who were at least partially BCGvaccinated, while TST is preferred for children younger than five years.

\section{COST-EFFECTIVENESS ANALYSIS OF IGRA IN PRACTICE}

A British study (45) compared the cost-effectiveness of screening for TB with IGRAs and TST alone and in combination. Examining the cost alone, the TST/ IGRA dual strategies cost less than IGRA alone strategies (about 160,000£ vs. 200,000£ per 1000 contacts, respectively). However, IGRA alone strategies are more specific for those who are really infected, reduce the number of people who need to be treated, and are more effective in preventing postexposure TB. When the cost of these strategies is compared with effectiveness, the TST/IGRA dual strategies are the most cost-effective (approximately $37,000 £$ per one case of prevented TB). TST alone is the least cost-effective (approximately 47,500 £ per one case of prevented TB). However, dual strategies are less effective in preventing active disease than screening with IGRA alone (45).

A similar study from Germany (46) also found the TST/QFT-G-IT strategy the most cost-effective in reducing the disease burden.

\section{IGRA IN NATIONAL TUBERCULOSIS PROGRAMMES}

Implementation of IGRAs in national tuberculosis programmes varies in terms of testing strategies and testing inclusion criteria. The US Centers for Disease Control and Prevention have suggested replacing TST with IGRAs in testing homeless persons, drug users, 
and persons who have received BCG as a vaccine or cancer therapy. Either a TST or an IGRA may be used without preference to test contacts of TB patients or for periodic screening of persons who might have occupational exposure to M. tuberculosis (27). Either the TST or an IGRA are recommended in Japan (except in children below five years of age), Denmark (for child contacts), Australia (for refugees) and France. In Switzerland and Denmark IGRA has replaced TST in patients receiving anti-TNF-alpha therapy. Canada, UK, Italy, Switzerland (for contacts), the Netherlands (for contacts and immigrants), Korea, Norway (for contacts), and Croatia recommend using IGRAs to confirm positive TST results $(3,34,47)$.

\section{BOOSTING EFFECT OF TST ON IGRA}

Many studies have pointed out that TST can boost IGRA result because both tests contain the same $M$. tuberculosis-specific antigens (48-53). This is relevant if TST and IGRA are used one after the other, as in two-step testings. This boosting effect has been observed on day three post TST and later $(47,54)$, and is more pronounced in IGRA-positive individuals. However, as many as two to twelve percent of otherwise IGRA-negative individuals experience a boost to IGRA-positive results after TST, which renders interpretation of two-step screening difficult (47). Current data can not answer when the boosting effect of TST on IGRA results stops, but the conventional wisdom is that it wanes after three months. Van Zyl-Smit et al. (47) conclude that IGRA testing performed before or within 72 hours of TST will not be subject to the boosting effect. In other words, the optimal time to collect blood for IGRA is at the time of reading TST.

\section{IGRA IN TESTING HEALTHCARE WORKERS}

The increased risk of TB in healthcare workers is well known $(55,56)$. In the US, serial screening for LTBI is part of the national guidelines and some hospital infection control programmes (57). In Croatia, healthcare worker screening has been performed only as part of contact tracing activities, while regular serial screening does not make part of the national tuberculosis programme.
Ever since the IGRAs have become part of TB screening, there is no general agreement about their role for this purpose. Regardless of many advantages over TST, the use of IGRAs for serial testing is limited, as there are no optimal cut-offs to distinguish new infections from nonspecific variations, and it is difficult to interpret conversion and reversion (29, 58-62).

Cut-off recommendations range between $0.2 \mathrm{IU} \mathrm{mL}^{-1}$ and $0.7 \mathrm{IU} \mathrm{mL}^{-1}$ of IFN-gamma, and retesting of borderline positive results is recommended before LTBI treatment $(31,63)$. However, many agree that repeated results in serial testing should be interpreted with caution, especially in countries with low TB incidence $(31,62)$.

\section{CONCLUSIONS AND POLICY IMPLICATIONS}

Immune-based tests such as TST and IGRAs share one important limitation. They do not directly detect M. tuberculosis. Instead, they detect remote or recent sensitisation to M. tuberculosis. A positive IGRA result may not necessarily indicate active tuberculosis, and a negative IGRA result does not exclude active disease. This also applies to TST. However, the negative predictive value of both tests (TST+IGRA combined) is high. Their positive predictive value depends on the prevalence of $M$. tuberculosis in a given population. Therefore, the gold standard for diagnosing active tuberculosis continues to be bacteriologically confirmed $M$. tuberculosis, but IGRA has a great potential in helping to identify LTBI.

The sensitivity of IGRAs may vary, but in general it is as high as or higher than TST sensitivity. All IGRAs have excellent specificity, and are certainly superior to TST, particularly in BCG-vaccinated patients. Furthermore, the agreement between TST and IGRAs is the lowest in these patients. Generally, the agreement between T-SPOT.TB and TST is higher than between QFT and TST, but these findings call for further investigation.

Although reproducibility of IGRAs is generally high, conversions and reversions may affect interpretation and procedures are still unclear in this respect.

IGRA sensitivity in children is suboptimal. To maximise sensitivity in children with a high risk of infection, especially in children below five years of 
age and in immunocompromised children, IGRA testing is recommended in addition to the TST. Lowrisk children may benefit from IGRAs as a confirmation of the positive TST in terms of increased specificity and reduced risk of a false diagnosis of LTBI. Children tend to have more IGRA-indeterminate results, which makes interpretation difficult.

Expert opinion is that immunocompromised patients could benefit from simultaneous use of IGRAs and TST. Indeterminate findings do not exclude TB infection. As a compromised immune system is too weak to respond to antigen stimulation, indeterminate results may actually point to LTBI, although these results should not be interpreted as positive.

In contact tracing studies, IGRA showed a good correlation with the infectiousness and the intensity of exposure to the source. IGRAs should not be used in monitoring TB or LTBI therapy or as a test of cure. Dual screening strategies (IGRA following positive TST) are more cost-effective than TST alone. It is generally accepted that TST may boost IGRA results, especially if IGRA is performed more than three days after TST. Therefore, the optimal time to collect blood for IGRA is at the time of TST reading.

IGRAs are an important advancement in the search for better diagnostic tests for LTBI. However, their performance still leaves much to be desired.

\section{REFERENCES}

1. Broekmans JF, Migliori GB, Rieder HL, Lees J, Ruutu P, Loddenkemper R, Raviglione MC; World Health Organization, International Union Against Tuberculosis and Lung Disease, and Royal Netherlands Tuberculosis Association Working Group. European framework for tuberculosis control and elimination in countries with a low incidence. Recommendations of the World Health Organization (WHO), International Union Against Tuberculosis and Lung Disease (IUATLD) and Royal Netherlands Tuberculosis Association (KNCV) Working Group. Eur Respir J 2002;19:765-75.

2. Jurčev-Savičević A, Katalinić-Janković V, Gjenero-Margan I, Šimunović A, Vidić Đ, Gunjača J, Obrovac M. Epidemiological patterns of tuberculosis in Croatia in the period 1996-2005. Coll Antropol 2011;35:523-8.

3. Ministry of Health and Social Welfare of the Republic Of Croatia and Croatian National Institute of Public Health. Guidelines for tuberculosis control. Zagreb: Ministry of Health and Social Welfare of the Republic Of Croatia and National Institute of Public Health; 2010.

4. Mack U, Migliori GB, Sester M, Rieder HL, Ehlers S, Goletti D, Bossink A, Magdorf K, Hölscher C, Kampmann B, Arend SM, Detjen A, Bothamley G, Zellweger JP, Milburn H, Diel R, Ravn P, Cobelens F, Cardona PJ, Kan B, Solovic I, Duarte R, Cirillo DM; C. Lange; TBNET. LTBI: latent tuberculosis infection or lasting immune responses to M. tuberculosis? A TBNET consensus statement. Eur Respir J 2009;33:95673

5. Lange $\mathrm{C}$, Mori $\mathrm{T}$. Advances in the diagnosis of tuberculosis. Respirology 2010;15:220-40.

6. Harada N, Higuchi K, Yoshiyama T, Kawabe Y, Fujita A, Sasaki Y, Horiba M, Mitarai S, Yonemaru M, Ogata H, Ariga H, Kurashima A, Wada A, Takamori M, Yamagishi F, Suzuki $\mathrm{K}$, Mori T, Ishikawa N. Comparison of the sensitivity and specificity of two whole blood interferon-gamma assays for M. tuberculosis infection. J Infect 2008;56:348-53.

7. Cellestis [displayed 13 June 2011]. Available at http://www. cellestis.com/

8. Lange C, Pai M, Drobniewski F, Migliori GB. Interferongamma release assays for the diagnosis of active tuberculosis: sensible or silly? Eur Respir J 2009;33:1250-3.

9. Lee SW, Oh DK, Lee SH, Kang HY, Lee CT, Yim JJ. Time interval to conversion of interferon-gamma release assay after exposure to tuberculosis. Eur Respir J 2011;37:1447-52.

10. Kobashi Y, Sugiu T, Mouri K, Obase Y, Miyashita N, Oka $\mathrm{M}$. Indeterminate results of QuantiFERON TB-2G test performed in routine clinical practice. Eur Respir J 2009;33:812-5.

11. Lalvani A, Pareek M. Interferon gamma release assays: principles and practice. Enferm Infecc Microbiol Clin 2010;28:245-52.

12. European Centre for Disease Prevention and Control. Use of interferon-gamma release assys in support of TB diagnosis. Stockholm: ECDC; 2011.

13. Sester M, Sotgiu G, Lange C, Giehl C, Girardi E, Migliori GB, Bossink A, Dheda K, Diel R, Dominguez J, Lipman M, Nemeth J, Ravn P, Winkler S, Huitric E, Sandgren A, Manissero D. Interferon- $\gamma$ release assays for the diagnosis of active tuberculosis: a systematic review and meta-analysis. Eur Respir J 2011;37:100-11.

14. Pai M, Zwerling A, Menzies D. Systematic review: T-cellbased assays for the diagnosis of latent tuberculosis infection: an update. Ann Intern Med 2008;149:177-84.

15. Diel R, Loddenkemper R, Nienhaus A. Evidence-based comparison of commercial interferon-gamma release assays for detecting active TB: a metaanalysis. Chest 2010;137:952-68.

16. Menzies D, Pai M, Comstock G. Meta-analysis: new tests for the diagnosis of latent tuberculosis infection: areas of uncertainty and recommendations for research. Ann Intern Med 2007;146:340-54.

17. Rieder HL. Epidemiologic Basis of Tuberculosis Control. Paris: IUATLD; 1999.

18. Ewer K, Millington KA, Deeks JJ, Alvarez L, Bryant G, Lalvani A. Dynamic antigen-specific T-cell responses after point-source exposure to Mycobacterium tuberculosis. Am J Respir Crit Care Med 2006;174:831-9.

19. Connell TG, Ritz N, Paxton GA, Buttery JP, Curtis N, Ranganathan SC. A three-way comparison of tuberculin skin testing, QuantiFERON-TB gold and T-SPOT.TB in children. PLoS One 2008;3:e2624.

20. Mori T. Usefulness of interferon-gamma release assays for diagnosing TB infection and problems with these assays. J Infect Chemother 2009;15:143-55.

21. Diel R, Loddenkemper R, Niemann S, Meywald-Walter K, Nienhaus A. Negative and positive predictive value of a 
whole-blood interferon-gamma release assay for developing active tuberculosis: an update. Am J Respir Crit Care Med 2011;183:88-95.

22. Higuchi K, Harada N, Mori T, Sekiya Y. Use of QuantiFERON-TB Gold to investigate tuberculosis contacts in a high school. Respirology 2007;12:88-92.

23. Dosanjh DP, Hinks TS, Innes JA, Deeks JJ, Pasvol G, Hackforth S, Varia H, Millington KA, Gunatheesan R, GuyotRevol V, Lalvani A. Improved diagnostic evaluation of suspected tuberculosis. Ann Intern Med 2008;148:32536.

24. Goletti D, Stefania C, Butera O, Amicosante M, Ernst M, Sauzullo I, Vullo V, Cirillo D, Borroni E, Markova R, Drenska R, Dominguez J, Latorre I, Angeletti C, Navarra A, Petrosillo N, Lauria FN, Ippolito G, Migliori GB, Lange C, Girardi E. Accuracy of immunodiagnostic tests for active tuberculosis using single and combined results: a multicenter TBNETStudy. PLoS One 2008;3:e3417.

25. Madariaga MG, Jalali Z, Swindells S. Clinical utility of interferon gamma assay in the diagnosis of tuberculosis. J Am Board Fam Med 2007;20:540-7.

26. Pai M, Kalantri S, Menzies D. Discordance between tuberculin skin test and interferon-gamma assays. Int J Tuberc Lung Dis 2006;10:942-3.

27. Mazurek GH, Jereb J, Vernon A, LoBue P, Goldberg S, Castro K; IGRA Expert Committee; Centers for Disease Control and Prevention (CDC). Updated guidelines for using Interferon Gamma Release Assays to detect Mycobacterium tuberculosis infection - United States, 2010. MMWR Recomm Rep 2010;59(RR-5):1-25.

28. Veerapathran A, Joshi R, Goswami K, Dogra S, Moodie EE, Reddy MV, Kalantri S, Schwartzman K, Behr MA, Menzies D, Pai M. T-cell assays for tuberculosis infection: deriving cut-offs for conversions using reproducibility data. PLoS One 2008;3:e1850.

29. Pai M, Joshi R, Dogra S, Mendiratta DK, Narang P, Kalantri S, Reingold AL, Colford JM Jr, Riley LW, Menzies D. Serial testing of health care workers for tuberculosis using interferon-gamma assay. Am J Respir Crit Care Med 2006; 174:349-55.

30. Pai M, O’Brien R. Serial testing for tuberculosis: can we make sense of T cell assay conversions and reversions? PLoS Med 2007;4:e208.

31. Ringshausen FC, Nienhaus A, Torres Costa J, Knoop H, Schlösser S, Schultze-Werninghaus G, Rohde G. Withinsubject variability of mycobacterium tuberculosis-specific gamma interferon responses in german health care workers Clin Vaccine Immunol 2011;18:1176-82.

32. Detjen AK, Loebenberg L, Grewal HM, Stanley K, Gutschmidt A, Kruger C, Du Plessis N, Kidd M, Beyers N, Walzl G, Hesseling AC. Short-term reproducibility of a commercial interferon gamma release assay. Clin Vaccine Immunol 2009;16:1170-5.

33. Bergamini BM, Losi M, Vaienti F, D'Amico R, Meccugni B, Meacci M, De Giovanni D, Rumpianesi F, Fabbri LM, Balli F, Richeldi L. Performance of commercial blood tests for the diagnosis of latent tuberculosis infection in children and adolescents. Pediatrics 2009;123:e419-24.

34. Pai M, Castro K, Mori T, Lienhardt C. Proceedings of the Second Global Symposium on Interferon-Gamma Release Assays. Session 9, Guidelines. Int J Tuberc Lung Dis 2010 June Suppl 1;14:S64-S69.
35. Diel R, Loytved G, Nienhaus A, Castell S, Detjen A, GeerdesFenge H, Haas W, Hauer B, Königstein B, Maffei D, Magdorf K, Priwitzer M, Zellweger JP, Loddenkemper R. Neue Empfehlungen für die Umgebungsuntersuchungen bei Tuberkulose [New recommendations for contact tracing in tuberculosis, in German]. Pneumologie 2011;65:359-78.

36. Lighter J, Rigaud M, Eduardo R, Peng CH, Pollack H. Latent tuberculosis diagnosis in children by using the QuantiFERON-TB Gold In-Tube test. Pediatrics 2009;123:30-7.

37. Mandalakas AM, Detjen AK, Hesseling AC, Benedetti A, Menzies D. Interferon-gamma release assays and childhood tuberculosis: systematic review and meta-analysis. Int $\mathrm{J}$ Tuberc Lung Dis 2011;15:1018-32.

38. Bruzzese E, Bocchino M, Assante LR, Alessio M, Bellofiore B, Bruzzese D, Iorio R, Matarese A, Santoro G, Vajro P, Guarino A, Sanduzzi A. Gamma interferon release assays for diagnosis of tuberculosis infection in immunecompromised children in a country in which the prevalence of tuberculosis is low. J Clin Microbiol 2009;47:2355-7.

39. Pavić I, Zrinski Topić R, Raos M, Aberle N, Dodig S. Interferon- $\gamma$ release assay for the diagnosis of latent tuberculosis in children younger than 5 years of age. Pediatr Infect Dis J 2011;30:866-70.

40. Piana F, Codecasa LR, Cavallerio P, Ferrarese M, Migliori GB, Barbarano L, Morra E, Cirillo DM. Use of a T-cellbased test for detection of tuberculosis infection among immunocompromised patients. Eur Respir J 2006;28:314.

41. Kim EY, Lim JE, Jung JY, Son JY, Lee KJ, Yoon YW, Park BH, Moon JW, Park MS, Kim YS, Kim SK, Chang J, Kang YA. Perfomance of the tuberculin skin test and interferongamma release assay for detection of tuberculosis infection in immunocompromised patients in a BCG-vaccinated population. BMC Infect Dis 2009;9:207.

42. Dyrhol-Riise AM, Gran G, Wenzel-Larsen T, Blomberg B, Haanshuus CG, Mørkve O. Diagnosis and follow-up of treatment of latent tuberculosis; the utility of the QuantiFERON-TB Gold In-tube assay in outpatients from a tuberculosis low-endemic country. BMC Infect Dis 2010;10:57.

43. Pai M, Joshi R, Bandyopadhyay M, Narang P, Dogra S, Taksande B, Kalantri S. Sensitivity of a whole-blood interferon-gamma assay among patients with pulmonary tuberculosis and variations in T-cell responses during antituberculosis treatment. Infection 2007;35:98-103.

44. Diel R, Loddenkemper R, Meywald-Walter K, Gottschalk $\mathrm{R}$, Nienhaus A. Comparative performance of tuberculin skin test, QuantiFERON-TB-Gold In Tube assay, and TSpot. TB test in contact investigations for tuberculosis. Chest 2009;135:1010-8

45. Pooran A, Booth H, Miller RF, Scott G, Badri M, Huggett JF, Rook G, Zumla A, Dheda K. Different screening strategies (single or dual) for the diagnosis of suspected latent tuberculosis: a cost effectiveness analysis. BMC Pulm Med 2010;10:7.

46. Diel R, Nienhaus A, Loddenkemper R. Cost-effectiveness of interferon-gamma release assay screening for latent tuberculosis infection treatment in Germany. Chest 2007;131:1424-34

47. Van Zyl-Smit RN, Zwerling A, Dheda K, Pai M. Withinsubject variability of interferon-g assay results for 
tuberculosis and boosting effect of tuberculin skin testing: a systematic review. PLoS One 2009;4:e8517.

48. Linas BP, Wong AY, Freedberg KA, Horsburgh Jr CR. Priorities for screening and treatment of latent tuberculosis infection in the United States. Am J Respir Crit Care Med 2011;184:590-601.

49. Choi JC, Shin JW, Kim JY, Park IW, Choi BW, Lee MK The effect of previous tuberculin skin test on the follow-up examination of whole-blood interferon-gamma assay in the screening for latent tuberculosis infection. Chest 2008;133:1415-20.

50. Perry S, Sanchez L, Yang S, Agarwal Z, Hurst P, Parsonnet J. Reproducibility of QuantiFERON-TB gold in-tube assay. Clin Vaccine Immunol 2008;15:425-32.

51. Baker CA, Thomas W, Stauffer WM, Peterson PK, Tsukayama DT. Serial testing of refugees for latent tuberculosis using the QuantiFERON-gold in-tube: effects of an antecedent tuberculin skin test. Am J Trop Med Hyg 2009;80:628-33.

52. Igari H, Watanabe A, Sato T. Booster phenomenon of QuantiFERON-TB Gold after prior intradermal PPD injection. Int J Tuberc Lung Dis 2007;11:788-91.

53. Naseer A, Naqvi S, Kampmann B. Evidence for boosting Mycobacterium tuberculosis-specific IFN-gamma responses at 6 weeks following tuberculin skin testing. Eur Respir J 2007;29:282-3.

54. Denkinger CM, Dheda K, Pai M. Guidelines on interferon- $\gamma$ release assays for tuberculosis infection: concordance, discordance or confusion? Clin Microbiol Infect 2011;17:806-14.

55. Seidler A, Nienhaus A, Diel R. Review of epidemiological studies on the occupational risk of tuberculosis in lowincidence areas. Respiration 2005;72:431-46.

56. Diel R, Seidler A, Nienhaus A, Rusch-Gerdes S, Niemann S. Occupational risk of tuberculosis transmission in a lowincidence area. Respir Res 2005;6:35-45.
57. Centers for Disease Control and Prevention (CDC). Guidelines for Preventing the Transmission of Mycobacterium tuberculosis in Health-Care Settings, 2005 [displayed 26. January 2012]. Available at http://www.cdc.gov/mmwr/ pdf/rr/rr5417.pdf

58. Pai M, Gokhale K, Joshi R, Dogra S, Kalantri S, Mendiratta DK, Narang P, Daley CL, Granich RM, Mazurek GH, Reingold AL, Riley LW, Colford JM Jr. Mycobacterium tuberculosis infection in health care workers in rural India: comparison of a whole-blood interferon gamma assay with tuberculin skin testing. JAMA 2005;293:2746-55.

59. Nienhaus A, Schablon A, Bâcle CL, Siano B, Diel R. Evaluation of the interferon-gamma release assay in healthcare workers. Int Arch Occup Environ Health 2008;81:295-300.

60. Torres Costa J, Sá R, Cardoso MJ, Silva R, Ferreira J, Ribeiro C, Miranda M, Plácido JL, Nienhaus A. Tuberculosis screening in Portuguese healthcare workers using the tuberculin skin test and the interferon-gamma release assay. Eur Respir J 2009;34:1423-8.

61. Tripodi D, Brunet-Courtois B, Nael V, Audrain M, Chailleux E, Germaud P, Naudin F, Muller JY, Bourrut-Lacouture M, Durand-Perdriel MH, Gordeeff C, Guillaumin G, Houdebine M, Raffi F, Boutoille D, Biron C, Potel G, Roedlich C, Geraut C, Schablon A, Nienhaus A. Evaluation of the tuberculin skin test and the interferon-gamma release assay for TB screening in French healthcare workers. J Occup Med Toxicol 2009;4:30.

62. Zwerling A, van den Hof S, Scholten J, Cobelens F, Menzies D, Pai M. Interferon-gamma release assays for tuberculosis screening of healthcare workers: a systematic review. Thorax 2012;67:62-70.

63. Torres Costa J, Silva R, Sá R, Cardoso MJ, Nienhaus A. Serial testing with the interferon- $\gamma$ release assay in Portuguese healthcare workers. Int Arch Occup Environ Health 2011;84:461-9. 


\section{Sažetak}

\section{ULOGA TESTOVA OTPUŠTANJA INTERFERONA GAMA U NADZORU NAD TUBERKULOZOM}

Tuberkuloza je i danas jedan od vodećih javnozdravstvenih problema. Zemlje s niskom incidencijom fokusiraju se na iscrpljivanje rezervoara budućih slučajeva sprječavanjem reaktivacije bolesti. To se odnosi na traženje i učinkovito liječenje inficiranih osoba, primarno onih koje su u riziku od obolijevanja nakon infekcije. Tuberkulinski test je od početka 20. stoljeća bio standard u otkrivanju imunosnog odgovora na kontakt s Mycobacterium tuberculosis. Novo tisućljeće donijelo je određeni napredak u obliku novih testova za dijagnozu latentne tuberkulozne infekcije, krvne testove otpuštanja interferona gama. Hrvatska je zemlja srednje incidencije tuberkuloze s dugogodišnjim silaznim trendom i razvijenim protutuberkuloznim aktivnostima. U težnji prema niskoj incidenciji i u konačnici eliminaciji tuberkuloze potrebne su opsežnije aktivnosti unutar državnog programa nadzora nad tuberkulozom, uključujući intenzivnu obradu kontakata i probir na postojanje latentne tuberkulozne infekcije. Ovaj rad razmatra trenutačnu uporabu IGRE (engl. interferon - gamma release assay) i njezinu ulogu u nadzoru nad tuberkulozom.

KLJUČNE RIJEČI: Hrvatska, ELISpot, latentna tuberkulozna infekcija, QuantiFERON-TB Gold InTube, tuberkulinski kožni test

CORRESPONDING AUTHOR:

Anamarija Jurčev-Savičević Vukovarska 46, 21000 Split, Croatia

E-mail:anamarijajs@gmail.com 